
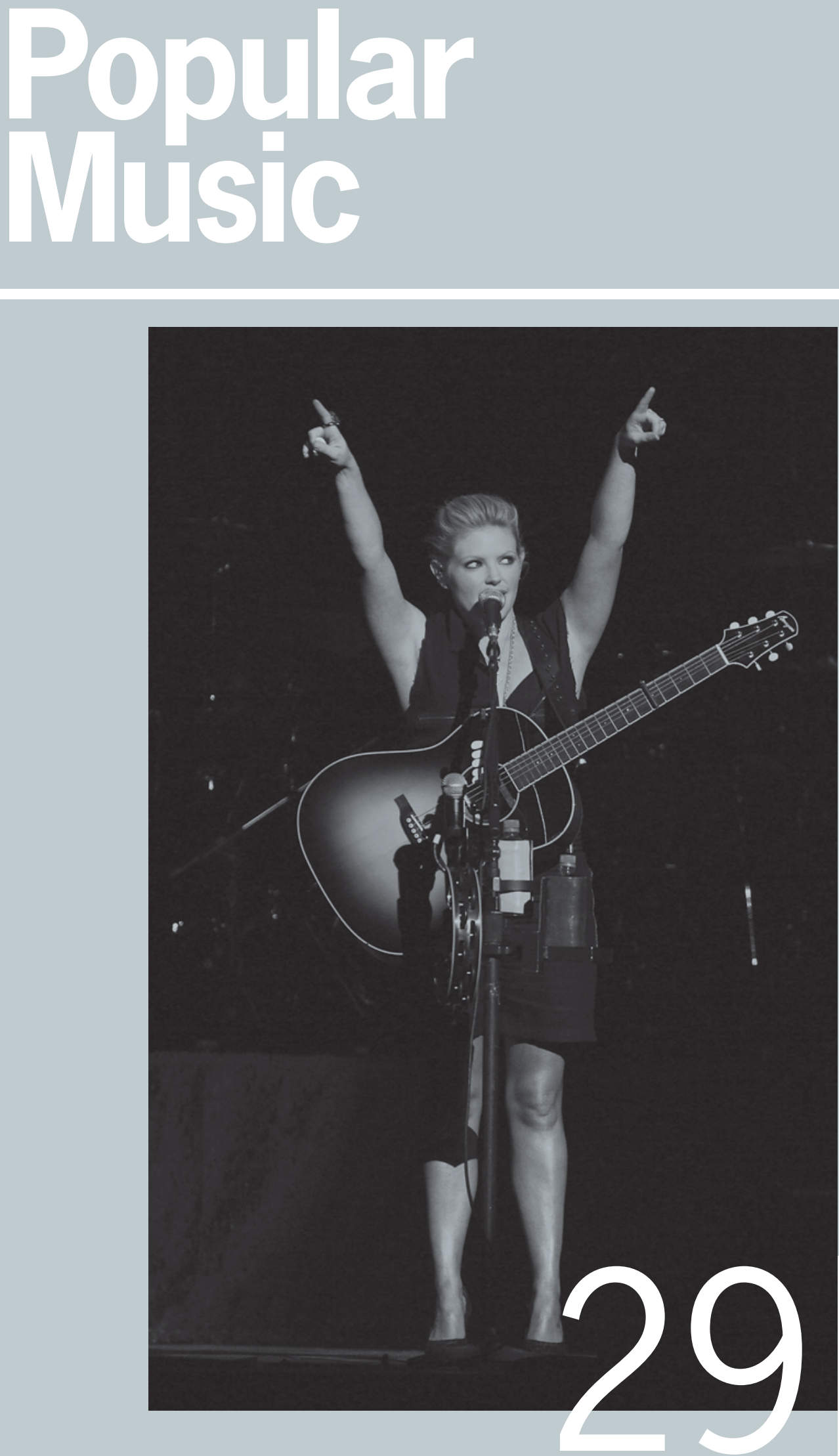


\section{Editorial Group}

MARTIN CLOONAN (Book Review Editor)

NICOLA DIBBEN (Co-ordinating Editor)

JAN FAIRLEY

SARAH HILL

\section{International Advisory Editors}

Christopher Ballantine (South Africa)

Alf Björnberg (Sweden)

David Brackett (USA)

Barbara Bradby (UK)

Sara Cohen (UK)

Franco Fabbri (Italy)

Simon Frith (UK)

Héctor Fouce (Spain)

Juan Pablo González (Chile)

Lucy Green (UK)

Line Grenier (Canada)

Dai Griffiths (UK)

Jill Halstead (Norway)

Charles Hamm (USA)

Deborah Pacini Hernández (USA)

David Hesmondhalgh (UK)
ALLAN MOORE

KEITH NEGUS (Co-ordinating Editor)

JOHN STREET

(C) Cambridge University Press 2010

Popular Music is a refereed multi-disciplinary journal which covers all aspects of popular music. It is published three times a year in January, May and October. Each issue contains substantial articles, shorter topical pieces, news and reviews. The editors also welcome polemical pieces for the 'Middle Eight' section of the journal. Contributors should consult the 'Notes' on the inside back cover.

Articles in triplicate, and any other material not related to reviews should be sent to Keith Negus, Dept of Music, Goldsmiths, University of London, London SE14 6NW, UK. Material for review should be sent to Professor Martin Cloonan, Department of Music, 14 University Gardens, University of Glasgow, Glasgow G12 8QH, Scotland, UK. Email m.cloonan@music.gla.ac.uk.

Subscriptions Popular Music (ISSN 0261-1430) is published three times a year in January, May and October. Three parts form a volume. The subscription price (excluding VAT) of Volume 29 which includes print and electronic access to institutional subscribers is $£ 163$ (USA, Canada and Mexico \$286); print only for individuals is $£ 44$ (USA, Canada and Mexico \$67). Single parts cost $£ 57$ (USA, Canada and Mexico \$100). An online only price is available to institutional subscribers for $£ 147$ (USA, Canada and Mexico \$257). EU subscribers (outside the UK) who are not registered for VAT should add VAT at their country's rate. VAT registered subscribers should provide their VAT registration number. Orders, which must be accompanied by payment, may be sent to a bookseller, subscription agent or direct to the publisher: Cambridge University Press, The Edinburgh Building, Shaftesbury Road, Cambridge CB2 8RU, UK. Orders from the USA, Canada and Mexico should be sent to Cambridge University Press, Journals Fulfillment Department, 100 Brook Hill Drive, West Nyack, New York 10994-2133. Japanese prices for institutions are available from Kinokuniya Company Ltd, P.O. Box 55, Chitose, Tokyo 156, Japan. Prices include delivery by air.

Claims for missing issues should be made immediately on receipt of the subsequent issue.

Copying This journal is registered with the Copyright Clearance Center, 222 Rosewood Drive, Danvers, MA 01923. Organizations in the USA who are also registered with the C.C.C. may therefore copy material (beyond the limits permitted by sections 107 and 108 of US copyright law) subject to payment to C.C.C. of the per copy fee of $\$ 12.00$. This consent does not extend to multiple copying for promotional or commercial purposes. Code 0261-1430/2010 \$12.00. Organizations authorized by the Copyright Licensing Agency may also copy material subject to the usual conditions.

ISI Tear Sheet Service, 3501 Market Street, Philadelphia, Pennsylvania 19104, USA, is authorized to supply single copies of separate articles for private use only.

For all other use, permission should be sought from the Cambridge or New York offices of Cambridge University Press.

INTERNET ACCESS This journal is included in the Cambridge Journals Online service at http:/ /journals.cambridge.org. For further information on Popular Music and all other Cambridge journals see http:/ / www.cambridge.org. 
VOL. 29 NO. 3

October

Issue Editors:

Keith Negus

John Street

\section{Popular Music}

\section{Contents}

\section{iii The Contributors}

JADA WATSON AND LORI BURNS ANDY BIRTWISTLE

JENNIFER SHRYANE

ED MONTANO

CHRIS ANDERTON

PETER STANFIELD

EMILY I. DOLAN

325 Resisting exile and asserting musical voice: the Dixie Chicks are 'Not Ready to Make Nice'

351 Marking time and sounding difference: Brubeck, temporality and modernity

373 'A small Utopia': Unterstützer not Anhänger. Einstürzende Neubauten's Supporter Initiative

397 'How do you know he's not playing Pac-Man while he's supposed to be DJing?': technology, formats and the digital future of DJ culture

417 A many-headed beast: progressive rock as European meta-genre

437 Crossover: Sam Katzman's Switchblade Calypso Bop Reefer Madness Swamp Girl or 'Bad Jazz,' calypso, beatniks and rock ' $n$ ' roll in 1950s teenpix

457 '... This little ukulele tells the truth': indie pop and kitsch authenticity'

\section{Middle Eight}

DAVE LAING 471 Remembering Pete and Charlie

\section{Reviews}

MICHAEL PICKERING RORY CRUTCHFIELD

DAVID COSPER

KEITH KAHN-HARRIS

CONRADO FALBO
473 Taking Popular Music Seriously, by Simon Frith

475 Segregating Sound: Inventing Folk and Pop Music in the Age of Jim Crow, by Karl Hagstrom Miller 478 Long Lost Blues: Popular Blues in America, 18501920, by Peter C. Muir

480 Playing Across a Divide: Israeli-Palestinian Musical Encounters, by Benjamin Brinner

482 A Language of Song - Journeys in the Musical World of the African Diaspora, by Samuel Charters 
JOE O'CONNELL 483 Rumba Rules: The Politics of Dance Music in Mobutu's Zaire, by Bob W. White

DAVID R. SHUMWAY

PAUL HARKINS

ALLAN MOORE

GREG GOLDBERG

HELEN O'SHEA

BRUCE JOHNSON

EVANGELOS

CHRYSAGIS

YNGVAR B. STEINHOLT

KEITH NEGUS

KATHERINE LEWIS

RICHARD ELLIOTT
485 How the Beatles Destroyed Rock ' $n$ ' Roll: An Alternative History of American Popular Music, by Elijah Wald

488 Reggaeton. Edited by Raquel Z. Rivera, Wayne Marshall, and Deborah Pacini Hernández

490 Everyday Tonality: Towards a Tonal Theory of What Most People Hear, by Philip Tagg

492 Edited Clean Version: Technology and the Culture of Control, by Raiford Guins

493 The Musical Traditions of Northern Ireland and its Diaspora, by David Cooper

495 Sound, Society and the Geography of Popular Music, edited by Ola Johansson and Thomas L. Bell

497 Paradosiaká: Music, Meaning and Identity in Modern Greece, by Elléni Kallimopoúlou 500 Mark E. Smith and The Fall: Art, Music and Politics, edited by Michael Goddard and Benjamin Halligan

502 Musical ImagiNation: U.S.-Colombian Identity and the Latin Music Boom, by María Elena Cepeda

504 Blackface Minstrelsy in Britain, by Michael Pickering

506 The Selling Sound: The Rise of the Country Music Industry, by Diane Pecknold 


\section{The Contributors}

CHRIS ANDERTON is a Senior Lecturer in Popular Music at Southampton Solent University. He received his PhD from Swansea University in 2007 and has published journal articles and book chapters examining British music festivals, not-for-profit bootlegging and Italian progressive rock. He is currently working on the co-edited book, Understanding the Music Industries, for Open University/McGraw-Hill.

ANDY BIRTWISTLE is Principal Lecturer in Film Radio and Television Studies at the Department of Media, Canterbury Christ Church University. His book, Cinesonica: sounding film and video, is published by Manchester University Press. He is also a practising sound artist, whose work has been broadcast and exhibited internationally.

LORI BURNS is Professor of Music and Vice Dean for Research of the Faculty of Arts at the University of Ottawa. Her work on popular music has been published in leading journals, edited collections and in monograph form (Disruptive Divas, Routledge). Her current program of research, with co-investigator Marc Lafrance, entitled 'Subjectivity, embodiment, and resistance in popular music by female artists', is funded by the Social Sciences and Humanities Research Council of Canada (2007-2010).

EMILY I. DOLAN is an Assistant Professor of Music at the University of Pennsylvania. Her research focuses on issues of timbre, orchestration and instrumentality. In particular, she is interested in the intersections between music, science and technology. She is completing a book, The Orchestral Revolution: Haydn and the Technologies of Timbre, 1750-1810.

ED MONTANO teaches on a popular music history course at Macquarie University in Sydney, works in music retail, and writes for the Australian dance music website www.inthemix.com.au. He has an MA in Popular Music Studies from the Institute of Popular Music at the University of Liverpool and a PhD on the commercial Sydney dance music scene from Macquarie University.

JENNIFER SHRYANE has taught Performance Arts since 1969 and for the last 15 years has been an examiner in this field. Her PhD study on Einstürzende Neubauten (University of Chester/Liverpool) was successfully completed in 2009. Her current research interests are German Populäre Musik (e.g. Abwärts, Ton Steine Scherben, Die Tödliche Doris), the performing body within this context and Artaud. Her book, Einstürzende Neubauten and German Experimental Music, is forthcoming from Ashgate.

PETER STANFIELD is Director of Film Studies at the University of Kent, and author of Body \& Soul: Jazz \& Blues in American Film, 1927-63 (2004), Horse Opera: The Strange History of the Singing Cowboy (2002), Hollywood, Westerns and the 1930s: The Lost Trail (2001), and joint-editor of Mob Culture: Hidden Histories of the American 
Gangster Film (2005), and 'Un-American' Hollywood: Politics E Film in the Blacklist Era (November 2007). His monograph Maximum Movies: Cinephilia $\mathcal{E}$ the Postwar Action Film is forthcoming.

JADA WATSON holds a BA and MA in Music History, and is completing a Master's in Information Studies at the University of Ottawa. Her research interests include issues of gender and geography in country music, and intersections of music and politics. She has presented papers on these topics at national and international conferences. 